Please do not remove this page

RMIT

UNIVERSITY

\title{
Drug detection dogs at Australian outdoor music festivals: Deterrent, detection and iatrogenic effects
}

Grigg, Jodie; Barratt, Monica; Lenton, Simon

https://researchrepository.rmit.edu.au/esploro/outputs/9921861104801341/filesAndLinks?institution=61RMIT_INST\&index=null

Grigg, J., Barratt, M., \& Lenton, S. (2018). Drug detection dogs at Australian outdoor music festivals:

Deterrent, detection and iatrogenic effects. International Journal of Drug Policy, 60, 89-95.

https://doi.org/10.1016/j.drugpo.2018.08.002

Document Version: Accepted Manuscript

Published Version: https://doi.org/10.1016/j.drugpo.2018.08.002

Repository homepage: https://researchrepository.rmit.edu.au

CC BY-NC-ND V4.0

(C) 2018 Elsevier B.V. All rights reserved.

Downloaded On 2023/04/27 01:23:15 +1000

Please do not remove this page 
Drug detection dogs at Australian outdoor music festivals: Deterrent, detection and iatrogenic effects

Jodie Grigg, PhD Candidate, National Drug Research Institute, Curtin University.

Monica J. Barratt, PhD, Research Fellow, Drug Policy Modelling Program, National Drug and Alcohol Research Centre, UNSW Australia; National Drug Research Institute, Curtin University; Behaviours and Health Risks Program, Burnet Institute

Simon Lenton, Professor and Director, National Drug Research Institute, Curtin University.

Corresponding author:

Jodie Grigg

GPO Box U1987

Perth WA 6845

Email: Jodie.grigg@postgrad.curtin.edu.au

Word count abstract $=300$ (Maximum of 300$)$

Word count body of paper $=4623$ (Maximum of 5000) 
Drug detection dogs at Australian outdoor music festivals: Deterrent, detection and iatrogenic effects

Keywords: Drug detection dogs, deterrence, drug policing, drug use, music festivals

\begin{abstract}
BACKGROUND: Recent drug-related deaths at Australian music festivals have led to increasing concern about the risk of future harm, but contention about how to effectively respond. One hotly debated strategy has been the use of drug detection dogs which currently operate at festivals across Australia, despite claims they are ineffective and contribute to risky drug use practices. This paper aims to investigate responses to the expected presence, and sightings, of drug dogs at the last festival attended.
\end{abstract}

METHODS: An anonymous online survey was completed by almost 2000 Australian festival-goers. The largest subsample used in the analyses for this paper $(n=647)$ was $59 \%$ male and had a median age of $20(\mathrm{IQR}=18-22)$.

RESULTS: Of those who expected dogs to be present at their last festival $(n=647)$, only $4 \%$ reported that this threat led them to decide not to take drugs. Other responses included: concealing their drugs well (48\%), getting someone else to carry their drugs (15\%), buying their drugs inside (11\%), taking less easily detected drugs $(10 \%)$ and taking drugs before entering $(7 \%)$. Of those who carried drugs in $(n=418), 10 \%$ concealed them internally and $1 \%$ swallowed them to retrieve inside. Of those who had drugs on their person when seeing a $\operatorname{dog}(n=189), 10 \%$ reported consuming drugs in response. No respondents reported being detected with drugs due to a positive identification.

CONCLUSION: Almost all festival-goers surveyed did not report being deterred from drug usage by the expected presence of drug dogs. Instead, a variety of alternative responses to avoid detection were reported, many of which could place festival-goers at greater risk of experiencing drug-related harms. In the face of mounting evidence of both ineffectiveness and iatrogenic effects, the use of drug detection dogs at Australian music festivals should be reconsidered. 


\section{Introduction}

According to media reports there have been at least 10 drug-related deaths linked to Australian outdoor music festivals in the past five years (Begley \& Arlington, 2015; Choahan, 2012; Johnson, Addie, \& Huffadine, 2017; McVeigh, 2017; Moskovitch, 2014; Partridge \& Ralston, 2013; Tonedeaf, 2015). These deaths have led to increasing concern about the risk of future drug-related harm and contention about how to effectively respond. One hotly debated strategy has been the use of drug detection dogs which currently operate at festivals around Australia, despite claims they are ineffective and increase the risk of drug-related deaths.

\section{The role of drug detection dogs}

In Australia, the use of specially trained drug detection dogs as a policing strategy emerged in the early 2000s in New South Wales (NSW) (Lancaster, Hughes, \& Ritter, 2016). The primary objective was to detect and prosecute persons involved in the sale of prohibited drugs (NSW Ombudsman, 2006). Since then, despite legal ambiguities (Meagher, 2009) and evidence of ineffectiveness (NSW Ombudsman, 2006), the strategy has been adopted and expanded across the country. The continued use of drug detection dogs has raised questions about existing approaches to illicit drugs policing in Australia, which one might have assumed to be evidence-based (Lancaster et al., 2016). To justify ongoing use of this strategy in the face of mounting evidence of ineffectiveness, a shifting rhetoric from 'detection' to the 'deterrent' effects of drug detection dogs has been identified (Lancaster et al., 2016). However, this justification is also problematic given limited evidence exists to prove they act as an effective deterrent (Hughes, Moxham-Hall, Ritter, Weatherburn, \& MacCoun, 2017), while growing evidence suggests they contribute to negative public health outcomes in settings such as outdoor music festivals (Dunn \& Degenhardt, 2009; Hickey, McIlwraith, Bruno, Matthews, \& Alati, 2012; Hughes et al., 2017; NSW Ombudsman, 2006).

\section{Evidence of effectiveness}

One of the first major sources of evidence in Australia undermining the use of drug detection dogs and fuelling ongoing debate was a review conducted by the NSW Ombudsman (NSW Ombudsman, 2006). The main conclusions provided following two years of monitoring were that drug detection 
dogs were ineffective at addressing the primary objective of detecting and prosecuting illicit drug suppliers, evident by a $74 \%$ false positive rate and less than $1 \%$ of positive indications resulting in successful prosecution. They also concluded there was no evidence to suggest this policing strategy had a deterrent effect, decreased drug-related crime or provided any other positive public health outcomes. However, they did identify negative public health outcomes, such as panic consumption, internal concealment, switching to less detectable but potentially more harmful drugs, opting to purchase inside from unknown sources and binging beforehand instead, concluding that this strategy may inadvertently cause harm by increasing risky drug use practices. This review therefore cast doubt on whether drug detection dogs were consistent with a harm minimisation approach, which has formed the basis of Australia's National Drug Strategy since 1985 (Ministerial Council on Drug Strategy, 2011).

Since the Ombudsman review, a growing body of academic literature has sought to investigate the deterrent, detection and other unintended iatrogenic effects of drug detection dogs in Australia. In 2009, a study of regular ecstasy users (REU) found the majority were not dissuaded from using drugs when made aware drug dogs would be operating at an event (Dunn \& Degenhardt, 2009). Rather, various precautions were taken in an attempt to avoid detection. Concerningly, there were also reports of hasty drug consumption when sighting dogs to avoid detection. While this study was limited by a small sample size, in 2012 researchers presented findings from a larger REU sample $(N=2127)$ over a three-year period which they claimed supported initial evidence (Hickey et al., 2012). This study noted that despite increasing visibility of drug dogs over the period, REU continued to be in possession of illicit drugs in public, purportedly demonstrating a limited deterrent effect. They also found that despite two-thirds having drugs on their person, less than $7 \%$ were positively identified. There were also more reports of hasty drug consumption when sighting drug dogs. More recently in 2017 a study investigated the impacts of different policing strategies on different types of drug offending among festival-goers using hypothetical policing vignettes (Hughes et al., 2017). These findings revealed that drug detection dogs were more effective than other policing strategies when it came to deterring drug use and possession, reducing use by $10.2 \%$ and possession by $15.7 \%$. 
However, the strategy was found to have a negligible impact on drug supply and actually increased buying of drugs inside festival grounds. Hughes et al. (2017) noted that this unintended consequence could have various deleterious effects, such as increasing risk to consumers who opt to obtain drugs inside the festival, and displacing criminal activity by increasing supply and demand for drugs inside events. While hypothetical vignettes have been proven as valid predictors of offending behaviour (as cited in Hughes et al., 2017; Pogarsky, 2009), the limitation remains that this study investigated intended, rather than actual, behaviour. Overall, however, these studies suggest that any deterrent effect on drug use should be considered in conjunction with its numerous other impacts (e.g. impacts on supply and demand and risky drug use practices) when determining whether it is an appropriate and effective policing strategy at outdoor music festivals.

\section{The policy setting}

The debate about this policing strategy continues to play out in Australia with input from various different sectors, including public health/policy advocates (Barklay, 2016; Cowdery \& Wodak, 2014; Tregoning, 2015), politicians (Barklay, 2016; Di Natale, 2016; Shoebridge, 2017), police (Hansen, 2017; Mullaney, 2015), legal experts (Malins, 2017; The Law Society of New South Wales, 2016), musicians (Baroni, 2014; Murphy, 2015) and the mainstream and alternative media (Harris, 2016; McVeigh, Tilley, \& McCormack, 2015; The Music, 2016; Triple j, 2016). The primary argument is focused on the effectiveness and adverse impacts of drug detection dogs in settings such as music festivals. While public health advocates claim drug detection dogs are ineffective at deterring drug use and can lead to risky practices like 'panic consumption', which has already been linked to two drugrelated deaths in Australia (Jarvis, 2014; Mulligan, 2013; Pedestrian, 2013; 2013), police have maintained that "drug dogs are saving lives" (Mullaney, 2015), "are an extremely effective deterrent" (Simmons, 2011) and the "[the strategy] is about minimising harm" (The Sydney Morning Herald, 2015). Another argument relates to cost-effectiveness, with opposing political parties seeking to uncover the cost of this strategy, which has been found to be in excess of 9 million dollars per year in NSW alone (Parliament of NSW, 2016; Triple j, 2016). There are also civil and human right arguments, with various legal groups advising that drug dog searches represent an unfair and 
unnecessary intrusion into people's privacy (NSW Ombudsman, 2006; The Law Society of New South Wales, 2016). Various targeted campaigns have also emerged, such as the Greens 'Sniff Off' campaign (Shoebridge, 2017) and Unharm's 'Ditch the Dogs' campaign (Tregoning, 2015). This ongoing debate may have helped illuminate potential inconsistencies between this policy and the available evidence, yet these divergent positions seem to have "culminated in a policy impasse" (Hughes et al., 2017).

In response to the shifting rhetoric regarding the deterrent effect of this policing strategy, further evidence is needed on actual behavioural responses to the expected presence of drug dogs at festivals (e.g. have festival-goers actually been deterred from using illicit drugs?). A greater understanding of the nature and extent of unintended iatrogenic effects is also critical for allowing a balanced evaluation of this policing strategy. While the strategy has already been found to be ineffective at addressing the primary aim (detecting drugs), further data on detection ability could help extend the evidence-base. Overall, the authors believe all sources of evidence on deterrence, detection and iatrogenic effects should be considered when evaluating the efficacy of this strategy.

\section{Aims}

Using data from a larger doctoral study of Australian festival-goers (Grigg, In preparation), this paper investigates:

1. Responses to the expected presence of drug detection dogs at the last festival attended (among those who had intended to take illicit drugs); and

2. Responses to seeing drug detection dogs at the last festival attended (among those who had illicit drugs on their person); and

3. The proportion detected with illicit drugs due to a positive identification (among those who saw drug detection dogs at the last festival attended and had illicit drugs on their person).

\section{Methods}

A large cross-sectional survey was conducted which investigated a range of drug-related issues in association with the last festival attended, such as drug use prevalence and patterns, protective and 
risk practices, obtaining and supplying illicit drugs, reasons for using drugs, positive and negative effects, access and barriers to first-aid and other HR strategies, experiences with police and attitudes towards drug policies. To address the first aim related to responses to the expected presence of drug dogs, this paper draws on data for the question 'When you heard/suspected in advance of arriving that drug detection dogs would be there, which of the following did you do?' $(n=647)$. The preceding question filtered out 563 respondents who were not expecting drug detection dogs to be present on the day. Additionally, 471 respondents who selected the response 'I wasn't intending on taking illicit drugs so it didn't affect me' were filtered out of the analysis for this paper. To address the second aim related to responses to drug dog sightings, this paper draws on data for the question 'When you saw the drug detection dogs, what did you do?' $(n=189)$. Respondents who did not see drug detection dogs at the last festival and/or did not have illicit drugs on their person were filtered out in the preceding questions. To address the third and final aim related to detection, this paper draws on data for the questions 'Which of the following types of police contact did you have: Stopped by police due to 'identification' by a drug detection dog?', filtered for those who saw drug detection dogs at the last festival and had illicit drugs on their person $(n=190)$ and "What was the outcome of being stopped by police due to an 'identification' by a drug detection dog?' $(n=10)$. Ethics approval was received by the Curtin University Human Research Ethics Committee (HR144/2015).

\section{Sample and recruitment}

The survey ran for seven weeks (May to July 2016) and received 3529 responses. After deleting ineligible cases, duplicate cases, and cases where less than 50\% of questions were completed, 1967 responses remained in the final sample. However, based on the filtering processes described above, different subsamples were included in the analyses for this paper. The eligibility criteria were: aged 16 and older, lived in Australia (in either states of Western Australia or Victoria) for the preceding 12 months and attendance at least one outdoor music festival in the preceding 12 months. The primary method of recruitment was paid Facebook advertising targeting populations based on their demographic characteristics and affiliation with Australian outdoor music festivals. Advertisements stated that participants would be prompted to enter an optional prize draw for a $\$ 500 \mathrm{JB}$ Hi-Fi e-gift 
card after submitting their responses. The survey was designed so it was not possible to link personal email addresses to individual survey responses. No reimbursement or other incentive was offered for taking part. Various music news and promotion websites, including Music Feeds, Beat Magazine, Inthemix, Tone Deaf and AAA Backstage, wrote articles promoting the survey which received shares on Facebook. The final sample was primarily recruited through Facebook ads $(89 \%)$, followed by snowballing and music news articles (each 5\%). The survey was developed using Qualtrics Survey Software (Qualtrics, 2016). Responses were anonymized in survey preferences to ensure no personal information, such as IP addresses, was collected.

\section{Data analysis}

Data analysis for this paper was primarily descriptive; however, chi-square tests of independence were used to determine whether there were significant differences between those expecting drug detection dogs to be present at the last festival versus those who were not expecting them (e.g. in terms of methods for carrying drugs into the festival). All data were analysed using SPSS Statistics 23 for Windows (IBM Corp., 2015).

\section{Results}

\section{Sample characteristics}

The median age of those who expected drug detection dogs to be at the last festival and were intending to take drugs was 20 years old $(\mathrm{IQR}=18-22$, range $=16-48)$ and more than half were male $(59 \%)(n=647)$. The majority were born in Australia (88\%) and spoke English at home (98\%). Most respondents 18 years old or over reported completing year 12 or equivalent $(92 \%)$ and approximately half reported completing a tertiary qualification (49\%). The majority reported living in their parents'/family home (60\%), followed by rented accommodation $(29 \%)$ and then their own home (9\%). Almost two-fifths reported full-time study (39\%) and about one-third reported full-time work (32\%). A breakdown of demographics for the key subsamples used in the analyses for this paper are included in a supplementary online table. 


\section{Responses to expected drug dog presence at the last festival}

Among those who expected drug detection dogs to be present at the last festival and were intending to take illicit drugs $(n=647)$, the most commonly reported response was 'planned to conceal them well' (48\%), followed by 'nothing, I just hoped for the best' (35\%). Although 'nothing, I just hoped for the best' suggests exclusivity, further analysis found the majority also selected other responses (89\%). Other common responses involved precautions to avoid contact, such as assessing the situation when they arrived and avoiding the dogs (26\%) or sending a spotter ahead (20\%), whereas some attempted to avoid the risk altogether by getting someone else to carry their drugs for them (15\%) or deciding to buy drugs inside (11\%). Some reported trying to minimise the risk by taking less easily detected drugs $(10 \%)$ or taking smaller quantities to the festival $(7 \%)$. The least commonly reported response was to make the decision not to take drugs at all on the day (4\%). A complete breakdown of responses is provided in Table 1.

\section{[Insert Table 1]}

\section{Other unintended responses to expected drug dog presence at the last festival}

Other unintended iatrogenic effects which may have resulted from the expected presence of drug detection dogs were also investigated. Table 2 provides a breakdown of results for those expecting drugs dogs to be present at the last festival they attended versus those who were not expecting them. Of those who carried their own illicit drugs into the festival and were expecting detection dogs to be present $(n=418), 10 \%$ reported concealing them internally in a body cavity and $1 \%(n=4)$ reported swallowing their drugs to retrieve once they got inside the festival grounds. The proportion reporting internal concealment was statistically significantly greater for those expecting drug detection dogs versus those who were not. Of those who were expecting drug dogs and obtained drugs inside the festival grounds $(n=238)$, two-fifths $(39 \%)$ reported doing so to avoid being detected by police before entering. Again, the proportion reporting obtaining inside to avoid detection was significantly greater for those expecting dogs to be present. Of those who supplied illicit drugs at the last festival and were expecting drug dogs $(n=171)$, approximately one-third (32\%) reported doing so to help a friend or partner who was concerned about carrying their own drugs in. 
[Insert Table 2]

\section{Responses to drug detection dog sightings at the last festival}

Less than one-third of respondents (28\%) reported actually seeing drug detection dogs at the last festival they attended (Table 3). Of those, two-fifths had illicit drugs on their person at the time. When respondents who had illicit drugs on them were asked about their response to seeing the drug dogs, almost half reported avoiding them (47\%), while $10 \%$ reported either consuming some or all of their drugs.

\section{[Insert Table 3]}

\section{Detection at the last festival among those who saw drug detection dogs}

Of all those who saw drug dogs at the last festival (including those not in possession of illicit drugs) $(n=467), 2 \%(n=10)$ were stopped due to a 'positive identification' from a drug detection dog. Of those who had illicit drugs on their person at the time, the proportion positively identified was $3 \%$ ( $n$ $=5)$. Of all those positively identified $(n=10)$, no illicit drugs were reportedly detected by police, despite half of them having illicit drugs on their person at the time. Thus, as evident in Table 4, no prosecutions for drug possession or supply reportedly resulted from this policing strategy in this sample.

[Insert Table 4]

\section{Discussion}

\section{Deterrent effect of drug detection dogs}

The present study sought to investigate responses to the expected presence of drug detection dogs at the last outdoor music festival respondents attended. One of the primary responses of interest was the deterrent effect of this policing strategy. The findings presented in this paper suggest that the expected presence of drug detection dogs did not deter the vast majority of festival-goers in this sample $(96 \%)$ from using illicit drugs at the last festival they attended. Rather, the threat of drug dogs appeared to result in a variety of alternative responses to avoid detection. 


\section{Other unintended iatrogenic effects of drug detection dogs}

Consistent with previous studies (Dunn \& Degenhardt, 2009), the most common response to the expected presence of drug detection dogs was planning to conceal their drugs well (48\%). Many festival-goers also decided to take precautions to minimise the risk of encountering drug detection dogs (e.g. sending spotters ahead and planning their arrival time), whereas some avoided personal risk altogether by getting their friends or partners to carry their drugs for them or by buying drugs inside the festival grounds instead. The latter finding supports Hughes et al. (2017) who identified buying drugs inside the festival as a potential consequence of this policing strategy. In agreeance with Hughes et al. (2017), this finding is concerning given festival-goers purchasing drugs inside the event are less likely to have knowledge about or past experience with those drugs. There may also be a heightened risk of purchasing drugs that are adulterated or misrepresented, as preference may be given to quick, conspicuous transactions, rather than considered ones. Consequently, decisions regarding drug use may be less informed for those obtaining drugs inside the festival. The finding that some respondents decided to get others to carry their drugs in for them suggests that some festivalgoers may be inadvertently putting themselves at risk of a more serious drug supply charge when they are only trying to help out their friends. This finding also raises questions about how many supply prosecutions resulting from drug policing in this context represent genuine supply offending, rather than 'social supply' (Lenton, Grigg, Scott, \& Barratt, 2016; Moyle, Coomber, \& Lowther, 2013). The finding that $10 \%$ decided to take drugs they considered less easily detected also provides confirmation of suspicions that some festival-goers may switch from using drugs like cannabis to potentially more risky drugs, like ecstasy, GHB or new psychoactive substances, which they perceive as less likely to be detected (Hughes et al., 2017; Jarvis, 2014). While some reported taking a smaller quantity of drugs to the festival (7\%), which has implications for minimising the risk of harm (or providing evidence of 'restrictive deterrence'), closer investigation revealed most (63\%) concomitantly reported responses which may increase risk, such as taking drugs before arriving (5\%), buying drugs inside the festival (23\%), taking less easily detected drugs (3\%) and getting friends to carry drugs in for them $(10 \%)$. Likewise, while using drugs before the festival only could potentially reduce risk if it represented a reduction in overall use, qualitative data from the larger study suggest this response 
typically involves binging (i.e. using drugs they may have otherwise spaced across the day) (Grigg, In preparation). Moreover, given studies suggest higher ambient temperatures may potentiate acute drug effects (Kiyatkin, Kim, Wakabayashi, Baumann, \& Shaham, 2014; Kiyatkin \& Ren, 2016), festivalgoers may be at greater risk of hyperthermia when using drugs beforehand in the warmer hours of the day. Unsurprisingly, qualitative data from the larger study identified a preference to pace drug use during the daytime and plan for peak intoxication during headlining acts in the night-time (i.e. in the cooler hours of the day) (Grigg, In preparation). This trajectory of use may represent lower risk of hyperthermia than binging beforehand to avoid detection.

Other iatrogenic effects identified which may have resulted from this policing strategy included hiding drugs internally in body cavities and swallowing drugs to retrieve inside the festival (e.g. via vomiting). While hiding drugs internally may have been a response to any type of drug policing at the festival, this behaviour appeared significantly more common among those expecting drug detection dogs to be present on the day. Additionally, anecdotal reports suggest some festival-goers believe concealing drugs internally can help mask the scent from drug detection dogs (Hansen, 2017). These methods for hiding drugs are of considerable concern given the clear health risk implications, such as inadequate concealment leading to drugs accidentally being absorbed by the body, the inability to vomit the drugs back up or accidental swallowing of drugs hidden in the mouth. Indeed, key stakeholders involved in the larger study provided anecdotal reports of festival-goers presenting to emergency departments unable to relocate and remove drugs concealed internally (Grigg, In preparation). Additionally, in 2015 it was reported that a young festival-goer saw drug detection dogs at 'A State of Trance' festival and decided to hide his drugs in a plastic bag in his mouth, but accidentally swallowed them, resulting in him being rushed to hospital (McClellan, 2015; Partridge, 2015). If this concealment trend continues at festivals, it is likely there will be more incidents involving the complications described above.

Another finding providing support for previous research (Dunn \& Degenhardt, 2009; Hickey et al., 2012) was that $10 \%$ of those in possession of illicit drugs reported swallowing them in response to seeing drug detection dogs at the last festival. While it is unclear whether this was in fact 'panic 
consumption' or planned behaviour in that situation, consuming drugs that were intended to be spaced across the day increases the risk of overdosing (Jarvis, 2014; Mulligan, 2013; Pedestrian, 2013). It may also increase the risk of experiencing adverse effects, given these festival-goers would be consuming drugs in a shorter space of time, in the warmer hours of the day, which again increase the risk of complications like hyperthermia (Kiyatkin, Kim, Wakabayashi, Baumann, \& Shaham, 2014; Kiyatkin \& Ren, 2016)

\section{Detection from positive drug detection dog identifications}

In terms of detection, it appeared that the majority of respondents $(97 \%)$ who had illicit drugs on their person when they saw drug dogs at the last festival went undetected. Interestingly, the $3 \%$ that were positively identified by drug detection dogs still managed to carry their drugs into the festival grounds as police performing the searches were unable to detect the drugs. Thus, no respondents in this sample reported that they were detected or prosecuted due to a positive identification from a drug detection dog at the last festival. The finding that police were unable to detect the drugs raised questions about whether the drugs were hidden internally and therefore unable to be easily detected by a police search. Interestingly, police have recently warned female festival-goers, who they claimed are increasingly hiding their drugs internally, that they will still be detected and prosecuted, even though they did not explain how this would be possible given current search powers do not allow searches of body cavities (Hansen, 2017). However, further analysis to explore this possibility revealed that those festival-goers whose drugs went undetected by police, despite a positive identification, were actually carrying their drugs in underwear or in a bag/wallet. These reportedly missed detections raise questions about the efficacy and thoroughness of current police search protocols. While one might then argue to increase the efficacy of police searches, given the legal ambiguities (Meagher, 2009), and opposition from civil liberties and legal groups (Malins, 2017; New South Wales Council for Civil Liberties, 2018; The Law Society of New South Wales, 2016), a more appropriate response may be to re-evaluate whether searches should take place at all. On a side note, if an argument was made to extend powers to allow cavity searches (to increase detection ability and deter internal concealment), this could trigger an increase in patrons opting to swallow their drugs and then purge them inside. 
This iatrogenic effect is arguably the most dangerous method of smuggling drugs into festivals and should therefore be seriously considered in the ongoing debate about drug policing at festivals. While acknowledging this method was rare in this cohort, there may have been underreporting due to stigma and/or distrust of how the data may be used. Overall, while it is possible festival-goers are using concealment methods which inhibit the ability for police to detect drugs, the findings presented here still call into question the efficacy of this policing strategy for drug detection in the context of outdoor music festivals.

\section{Limitations and strengths}

This study had a number of limitations. Firstly, a purposive, rather than probability, sample was recruited. Consequently, the results cannot be viewed as representative of the wider population of Australian festival-goers. Secondly, it is not known how close respondents were to the drug detection dogs when seeing them at the last festival. Accordingly, the detection rate should be interpreted with caution as some respondents may have been out of the detection range or there may not have been enough dogs present to pursue everyone who was emitting a drug scent. Thirdly, when interpreting the deterrent effect, it is important to consider the possibility that respondents were drawing on different past experiences with this policing strategy, which may have presented varying levels of risk. For example, some respondents may have attended festivals with multiple entrance lines and only one drug detection dog, whereas others may have attended festivals with only one entrance line and multiple detection dogs. Therefore, different past experiences may have resulted in varying perceptions of risk associated with this policing strategy. Finally, it should be noted that this question was asked to all respondents who were expecting drug detection dogs to be present at the last festival they attended, but there may have been varying levels of certainty. Future research may benefit from collecting data about different levels of expectation (e.g. likelihood dogs will be present and how many they expect will be present) and investigating how that affects responses. Notwithstanding these limitations, the present study extends the existing literature as it appears to be the first in Australia to investigate actual behavioural responses to the expected presence, and sighting, of drug detection dogs specifically in the context of the last outdoor music festival attended. 


\section{Conclusion}

In summary, almost all festival-goers surveyed did not report being deterred from drug usage by the expected presence of drug detection dogs. Instead, a variety of alternative responses to avoid detection were reported, many of which could place festival-goers at greater risk of experiencing a range of drug-related harms. The findings also suggest this policing strategy was largely ineffective at detecting drugs on festival-goers. In the face of mounting evidence of both ineffectiveness and iatrogenic effects, the use of drug detection dogs at Australian outdoor music festivals should be urgently reconsidered. Moving forward, consideration should be given to more evidence-informed responses which are consistent with Australia's harm minimisation policy. Accumulating evidence suggests drug checking services have the capacity to effectively deter festival-goers from using dangerous drugs and using drugs in dangerous ways (Barratt, Bruno, Ezard, \& Ritter, 2017; Sage, 2016; Sullivan, 2018). Expanding trials of this intervention across Australia should therefore be considered as an approach for reducing the overall harmfulness of drug use in these settings. 


\section{Acknowledgements}

Thank you to all the festival-goers who generously donated their time to complete the online survey. This doctoral research was funded by a scholarship from the Australian Government Department of Health. Monica Barratt is supported by a fellowship from the National Health and Medical Research Council (APP1070140). The National Drug and Alcohol Research Centre and the National Drug Research Institute are supported by funding from the Australian Government under the Substance Misuse Prevention and Service Improvement Grants Fund.

\section{Declaration of interests}

There are no relevant interests to declare. 


\section{References}

Barklay, A. (2016). Sniffer dogs have had their day: experts, Greens. Retrieved from Alt media website: http://www.altmedia.net.au/sniffer-dogs-have-had-their-day-experts-greens/114560

Baroni, N. (2014). Art Vs Science's Dan Mac Appeals For No Sniffer Dogs At Splendour. Retrieved from Music Feeds website: http://musicfeeds.com.au/news/art-vs-sciences-dan-mac-appealsfor-no-sniffer-dogs-at-splendour/

Barratt, M. J., Bruno, R., Ezard, N., \& Ritter, A. (2017). Pill testing or drug checking in Australia: Acceptability of service design features. Drug and Alcohol Review. doi:10.1111/dar.12576

Begley, P., \& Arlington, K. (2015, 07/12/2015). Police warnings not enough to stop festival deaths: Drug educator. The Sydney Morning Herald. Retrieved from

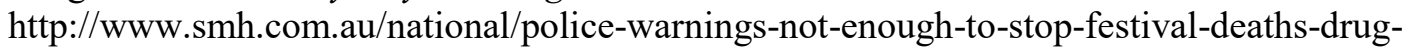
educator-20151207-glhfqz.html

Choahan, N. (2012, 31/01/2012). 'Everything is very odd here': Daniel dials mum as music festival turns to tragedy. The Sydney Morning Herald. Retrieved from

$\mathrm{http} / / / \mathrm{www} . \mathrm{smh} . \mathrm{com} . \mathrm{au} / \mathrm{entertainment/music/everything-is-very-odd-here-daniel-dials-mum-}$ as-music-festival-turns-to-tragedy-20120130-1qpo4.html

Cowdery, N., \& Wodak, A. (2014). Drug surveillance operations an abject failure. Retrieved from The Sydney Morning Herald website: https://www.smh.com.au/opinion/drug-surveillanceoperations-an-abject-failure-20141126-1 lucdp.html

Di Natale, R. (2016). Senate says Government should cease use of sniffer dogs at festivals. Retrieved from The Australian Greens website: http://greensmps.org.au/content/media-releases/senatesays-government-should-cease-use-sniffer-dogs-festivals

Dunn, M., \& Degenhardt, L. (2009). The use of drug detection dogs in Sydney, Australia. Drug and Alcohol Review, 28(6), 658-662. doi:10.1111/j.1465-3362.2009.00065.x

Grigg, J. (In preparation). A mixed-methods study of drug use at outdoor music festivals in Western Australia and Victoria. (Doctor of Philosophy), Curtin University, Perth, Australia.

Hansen, N. (2017, 6/03/2017). Police warn of women 'internally concealing drugs' after swoop on Sydney's Supremacy music festival. The Daily Telegraph. Retrieved from http://www.dailytelegraph.com.au/news/nsw/police-warn-of-women-internally-concealingdrugs-after-swoop-on-sydneys-supremacy-music-festival/newsstory/aa505a9d6940dc95851286a0bd7abae9

Harris, L. (2016). Reporter offered drugs before even inside Listen Out festival despite heavy police presence. Retrieved from The Daily Telegraph website:

http://www.dailytelegraph.com.au/news/nsw/reporter-offered-drugs-before-even-insidelisten-out-festival-despite-heavy-police-presence/newsstory/2b7562c4688124f91079f3cfdf8ad21c

Hickey, S., McIlwraith, F., Bruno, R., Matthews, A., \& Alati, R. (2012). Drug detection dogs in Australia: More bark than bite? Drug and Alcohol Review, 31(6), 778-783. doi:10.1111/j.1465-3362.2012.00431.x

Hughes, C. E., Moxham-Hall, V. L., Ritter, A., Weatherburn, D., \& MacCoun, R. (2017). The deterrent effects of Australian street-level drug law enforcement on illicit drug offending at outdoor music festivals. International Journal of Drug Policy. doi:10.1016/j.drugpo.2016.12.018

IBM Corp. (2015). IBM SPSS Statistics for Windows, Version 23.0. Armonk, NY: IBM Corp.

Jarvis, N. (2014, 16/07/2014). Drug research experts agree with banning sniffer dogs at festivals. Inthemix. Retrieved from

http://www.inthemix.com.au/news/58524/Drug_research_experts_agree_with_banning_sniffe r_dogs at festivals

Johnson, S., Addie, R., \& Huffadine, L. (2017, 3/01/2017). Nimbin man Jake Monahan dies after taking substance at Mount Lindesay New Year's Eve party. Daily Mail Australia. Retrieved from http://www.dailymail.co.uk/news/article-4081456/Nimbin-man-Jake-Monahan-diestaking-substance-Mount-Lindesay-New-Year-s-Eve-party.html

Kiyatkin, E. A., Kim, A. H., Wakabayashi, K. T., Baumann, M. H., \& Shaham, Y. (2014). Critical role of peripheral vasoconstriction in fatal brain hyperthermia induced by MDMA (Ecstasy) 
under conditions that mimic human drug use. Journal of Neuroscience, 34(23), 7754-7762. doi:10.1523/jneurosci.0506-14.2014

Kiyatkin, E. A., \& Ren, S. E. (2016). MDMA, Methylone, and MDPV: Drug-Induced Brain Hyperthermia and Its Modulation by Activity State and Environment. Current Topics in Behavioral Neurosciences. doi:10.1007/7854_2016_35

Lancaster, K., Hughes, C. E., \& Ritter, A. (2016). 'Drug dogs unleashed': An historical and political account of drug detection dogs for street-level policing of illicit drugs in New South Wales, Australia. Australian and New Zealand Journal of Criminology, 0(0), 1-19. doi:10.1177/0004865816642826

Lenton, S., Grigg, J., Scott, J., \& Barratt, M. (2016). The social supply of cannabis in Australia: Definitional challenges and regulatory possibilities. In B. Werse \& C. Bernard (Eds.), Friendly Business: International Views on Social Supply, Self-Supply and Small-Scale Drug Dealing (pp. 29-46). Wiesbaden: Springer Fachmedien Wiesbaden.

Malins, P. (2017). Sniffer dogs at festivals doing more harm than good says expert. Retrieved from The Conversation website: http://dopamine.net.au/sniffer-dogs-festivals-peta-malins/

McClellan, B. (2015, 9/02/2015). Teenager dies, another man critical, after A State of Trance festival at Sydney Olympic Park. The Daily Telegraph. Retrieved from http://www.dailytelegraph.com.au/news/teenager-dies-another-man-critical-after-a-state-oftrance-festival-at-sydney-olympic-park/news-story/141c4fe1a062ef8447f19ea90ae58822

McVeigh, S. (2017, 1/02/2017). Man who died at Rainbow Serpent drank amyl nitrite 'poppers', sources say. The Hack Half Hour. Retrieved from http://www.abc.net.au/triplej/programs/hack/man-dead-rainbow-serpent-drunk-amyl-nitritepoppers-sources-say/8227740

(2015, 2/12/2015). Sniffer dogs and strip searches at music festivals [Retrieved from http://www.abc.net.au/triplej/programs/hack/strip-searches-at-festivals:-what-are-yourrights/6984906

Meagher, D. (2009). The status of using drug detection dogs under Australian law. Criminal Law Journal, 33, 165-174.

Ministerial Council on Drug Strategy. (2011). National Drug Strategy 2010-2015: a framework for action on alcohol, tobacco and other drugs, 2011. Canberra: Commonwealth of Australia Retrieved from http://www.nationaldrugstrategy.gov.au/internet/drugstrategy/publishing.nsf/Content/DB4076 D49F13309FCA257854007BAF30/\$File/nds2015.pdf.

Moskovitch, G. (2014, 31/12/2014). Man found dead at Falls Festival Byron Bay campsite. Tonedeaf. Retrieved from http://www.tonedeaf.com.au/430105/man-found-dead-falls-festival-byronbay-campsite.htm

Moyle, L., Coomber, R., \& Lowther, J. (2013). Crushing a walnut with a sledge hammer? Analysing the penal response to the social supply of illicit drugs. Social and Legal Studies, 22(4), 553573. doi:10.1177/0964663913487544

Mullaney, A. (2015, 29/05/2015). Greens want a leash on drug dogs. The Daily Telegraph. Retrieved from http://www.dailytelegraph.com.au/news/nsw/greens-want-a-leash-on-drug-dogs/newsstory/c25fbfb1b3a062a57c97ce7ecc72d7ad

Mulligan, D. H. (2013). Record of investigation into death (Inquest into the death of Gemma Geraldine THOMS). Perth, WA: Office of the State Coroner.

Murphy, S. (2015). Paul Mac, Art Vs. Science Support NSW Greens Bill To Stop Use Of Sniffer Dogs. Retrieved from Music Feeds website: http://musicfeeds.com.au/news/paul-mac-art-vsscience-support-nsw-greens-bill-to-stop-use-of-sniffer-dogs/

New South Wales Council for Civil Liberties. (2018). Police sniffer dogs. Retrieved from http://www.nswccl.org.au/police_sniffer_dogs

NSW Ombudsman. (2006). Review of the Police Powers (Drug Detection Dogs) Act 2001. In. Sydney: Office of the New South Wales Ombudsman.

Parliament of NSW. (2016). Legislative council questions and answers. Sydney, NSW: Parliament of NSW Retrieved from https://www.parliament.nsw.gov.au/lc/papers/Documents/2016/3-may2016-questions-and-answers/QA_54_03_MAY_2016.pdf. 
Partridge, E. (2015). Deadly game played at Sydney 'A State of Trance' dance party, police say. Sydney Morning Herald. Retrieved from http://www.smh.com.au/nsw/deadly-game-playedat-sydney-a-state-of-trance-dance-party-police-say-20150209-139rlw.html

Partridge, E., \& Ralston, N. (2013, 17/09/2013). Drug victim was found alone before his death. The Sydney Morning Herald. Retrieved from http://www.smh.com.au/entertainment/music/drugvictim-was-found-alone-before-his-death-20130916-2tv6k.html

Pedestrian. (2013, 17/03/2017). Defqon.1 drugs death reignites sniffer dog debate. Pedestrian. Retrieved from https://www.pedestrian.tv/news/arts-and-culture/defqon1-drugs-deathreignites-sniffer-dogs-debate/66ab2c3c-00e4-4d67-a718-69adec7f47e2.htm

Pogarsky, G. (2009). Deterrence and decision making: Research questions and theoretical refinements. In M. D. Krohn, A. J. Lizotte, \& G. P. Hall (Eds.), Handbook on Crime and Deviance (pp. 241-258). New York, NY: Springer New York.

Sage, C. (2016). Harm Reduction and Drug Checking; A wrap-around service for festivals. Case Study: Shambhala Music Festival /ANKORS Drug Checking Harm Reduction Service data 2015. In. Nelson, BC, Canada: ANKORS.

Shoebridge, D. (2017). Sniff off: No more drug dogs! Retrieved from http://davidshoebridge.org.au/sniffoff/

Simmons, A. (2011, 12/12/2011). Accuracy of police sniffer dogs called into question. ABC News. Retrieved from http://www.abc.net.au/news/2011-12-12/accuracy-of-police-sniffer-dogscalled-into-question $/ 3726228$

Sullivan, R. (2018). Groovin The Moo Pill-Testing: Deadly Pills discovered on first weekend. Retrieved from News.com.au website: http://www.news.com.au/lifestyle/real-life/newslife/two-deadly-pills-found-during-australias-first-pill-testing-trial-at-groovin-the-moofestival-in-canberra/news-story/caeeaa2a2479cc1abb8fefba5a8a4842

The Law Society of New South Wales. (2016). Comment on 'Law Enforcement (Powers and Responsibilities) Amendment (Sniffer Dogs-Repeal of Powers) Bill 2016'. In. Sydney, NSW: The Law Society of New South Wales.

The Music. (2016). Greens Motion On Pill Tests \& Drug Dogs Passes Senate But Maybe Don't Get Too Excited Yet. Retrieved from The Music website: http://themusic.com.au/news/all/2016/09/01/greens-motion-on-pill-testing-sniffer-dogspasses-senate-but-maybe-dont-get-too-excited-yet/

The Sydney Morning Herald. (2015, 29/11/2015). Woman dies at Stereosonic music festival as dozens charged with drug offences. The Sydney Morning Herald. Retrieved from $\mathrm{http} / / / \mathrm{www} . \mathrm{smh} . c 0 m . \mathrm{au} / \mathrm{nsw} /$ woman-dies-at-stereosonic-music-festival-as-dozens-chargedwith-drug-offenses-20151128-glam35.html

Tonedeaf. (2015, 07/12/2015). Six dead, countless overdoses: Why has Australia's music festival culture turned deadly? Tonedeaf. Retrieved from http://www.tonedeaf.com.au/466572/arethe-recent-deaths-at-aussie-music-festivals-a-cultural-problem.htm

Tregoning, W. (2015, 27/02/2015). \#ditchthedogs. Retrieved from http://www.unharm.org/ditchthedogs_infographic

Triple j. $(2016,25 / 05 / 2016)$. We now know sniffer dogs cost NSW more than $\$ 9 \mathrm{~m}$ per year. The Hack Half Hour. Retrieved from http://www.abc.net.au/triplej/programs/hack/drug-dogs-cost-nsw9-million-per-year/7444908

Whitehead, L. (2013, 14/10/2013). Grieving father gives personal warning about buying drugs online. ABC News. Retrieved from http://mobile.abc.net.au/news/2013-10-14/grieving-father-givespersonal-warning-about/5022062\#transcript 
Table 1: Responses to the expected presence of drug detection dogs at the last festival (among those who were intending to take illicit drugs) (\%)

\begin{tabular}{lc}
\hline Response to expected drug dog presence at the last festival & n=647 \\
\hline Planned to conceal them well & 48 \\
Nothing, I just hoped for the best ${ }^{\text {a }}$ & 35 \\
Decided to assess the situation when I arrived and avoid them & 26 \\
Decided to send a spotter ahead/call a friend to report back police activity, drug dogs, etc. & 20 \\
Got someone else to carry my drugs in for me & 15 \\
Decided to time my arrival to avoid them & 15 \\
Decided to try and buy drugs inside the festival & 11 \\
Decided to take drugs less easily detected by the dogs & 10 \\
Decided to take drugs before the festival, but not during & 7 \\
Decided to take a smaller quantity of drugs to the festival & 7 \\
Decided NOT to take drugs at all that day & 4 \\
Other & 3 \\
\hline
\end{tabular}

Note. Multiple responses were allowed therefore the total may exceed $100 \%$.

${ }^{a}$ Only $11 \%(n=74)$ selected this response option exclusively. This indicates that while they hoped for the best, they also engaged in other precautions. 


\begin{tabular}{lcccc}
\hline Other iatrogenic effects & $\begin{array}{c}\text { Expecting } \\
\text { drug dogs }\end{array}$ & $\begin{array}{c}\text { Not } \\
\text { expecting } \\
\text { drug dogs }\end{array}$ & Total & $\begin{array}{c}\boldsymbol{p} \\
\text { chi sq }\end{array}$ \\
\hline $\begin{array}{l}\text { Of those who carried their own drugs: Concealed } \\
\text { drugs internally in a body cavity }\end{array}$ & $n=418$ & $n=219$ & $n=637$ & $0.001^{*}$ \\
$\begin{array}{l}\text { Of those who carried their own drugs: Swallowed } \\
\text { drugs and then retrieved them once inside the festival } \\
\text { (i.e. } \text { vomited them) }\end{array}$ & $n=418$ & $n=219$ & $n=637$ & \# \\
$\begin{array}{l}\text { Of those who obtained inside: Did so because they } \\
\text { were concerned about being detected with drugs }\end{array}$ & $n=238$ & $n=108$ & $n=346$ & $<0.001^{*}$ \\
before entering & 39 & 13 & 31 & $n=271$ \\
$\begin{array}{l}\text { Of those who supplied: Did so to help a friend/partner } \\
\text { concerned about carrying them in }\end{array}$ & $n=171$ & $n=100$ & 28 & 0.060 \\
\hline
\end{tabular}

$* \mathrm{p}=0.001$.

\#Cell sizes were too small for statistical analysis. 
Table 3: Response to seeing drug detection dogs at the last festival (\%)

\begin{tabular}{lc}
\hline Variable & (\%) \\
\hline Did you see any drug detection dogs outside or nearby the LAST music festival you attended? & $n=1674$ \\
Yes & 28 \\
No & 50 \\
Don't know/can't remember & 22 \\
When you saw the drug detection dogs, did you have illicit drugs on you? & $n=470$ \\
Had illicit drugs on my person & 40 \\
Did not have illicit drugs on my person & 57 \\
Don't know/can't remember & 3 \\
Of those who had illicit drugs on them: When you saw the drug detection dogs, what did you do? & $n=189$ \\
Nothing, just hoped for the best & $64^{\mathrm{b}}$ \\
Just avoided the police and drug dogs & 47 \\
Consumed some of the drugs I had & 8 \\
Consumed all the drugs I had & 2 \\
Gave them to a friend (who carried them in for me) & 1 \\
Dropped them on the ground & 1 \\
Other & 5 \\
\hline
\end{tabular}

${ }^{a}$ Multiple responses were allowed so the total may exceed $100 \%$.

b Only 44\% ( $n=84)$ selected this response option exclusively. This indicates that while they hoped for the best, they also engaged in other behaviours to avoid detection. 
Table 4: Identification by a drug detection dog at the last festival (among those who saw drug dogs there) (\%)

\begin{tabular}{lc}
\hline Variable & (\%) \\
\hline Stopped by police due to an 'identification' by a drug dog & $n=467$ \\
& $2(n=10)$ \\
Stopped by police due to an 'identification' by a drug dog (among those who had illicit drugs on & $n=190$ \\
their person at the time) & $3(n=5)$ \\
Outcome of being stopped due to an 'identification': & $n=10$ \\
They DID NOT find drugs (because I had no drugs on me) & 50 \\
They DID NOT find drugs (even though I had drugs on me) & 50 \\
\hline
\end{tabular}




\begin{tabular}{|c|c|c|c|}
\hline & $\begin{array}{l}\text { Expected drug dogs } \\
\text { and were intending } \\
\text { to take illicit drugs } \\
\qquad n=647\end{array}$ & $\begin{array}{c}\text { Saw drug dogs and } \\
\text { had illicit drugs on } \\
\text { their person } \\
n=190\end{array}$ & $\begin{array}{c}\text { Positively identified } \\
\text { by drug detection } \\
\text { dogs } \\
n=10\end{array}$ \\
\hline \multirow{2}{*}{ Median age (IQR) } & $n=647$ & $n=190$ & $n=10$ \\
\hline & $20(18-22)$ & $20(19-22)$ & $22(18-24)$ \\
\hline \multirow{2}{*}{ Underage (under 18) (\%) } & $n=647$ & $n=190$ & $n=10$ \\
\hline & 14 & 10 & 10 \\
\hline \multirow{2}{*}{ Gender- male (\%) } & $n=647$ & $n=190$ & $n=10$ \\
\hline & 59 & 65 & 90 \\
\hline \multirow{2}{*}{ Born in Australia (\%) } & $n=607$ & $n=178$ & $n=9$ \\
\hline & 88 & 84 & 89 \\
\hline \multirow{2}{*}{ Speak English at home (\%) } & $n=601$ & $n=178$ & $n=9$ \\
\hline & 98 & 96 & 89 \\
\hline \multirow{2}{*}{ Sexual identity- Heterosexual (\%) } & $n=608$ & $n=179$ & $n=9$ \\
\hline & 89 & 89 & 67 \\
\hline Marital status ${ }^{\mathrm{a}}(\%)$ & $n=607$ & $n=179$ & $n=9$ \\
\hline Never married & 94 & 93 & 100 \\
\hline Married & 6 & 7 & 0 \\
\hline Other & $<1$ & 1 & 0 \\
\hline Location $(\%)$ & $n=608$ & $n=179$ & $n=9$ \\
\hline Inner city & 9 & 11 & 11 \\
\hline Inner suburbs & 45 & 49 & 22 \\
\hline Outer suburbs & 33 & 30 & 33 \\
\hline Regional & 12 & 10 & 33 \\
\hline Remote & 1 & 1 & 0 \\
\hline Don't know & $<1$ & 0 & 0 \\
\hline Accommodation (\%) & $n=607$ & $n=179$ & $n=9$ \\
\hline Own house & 9 & 11 & 11 \\
\hline Rented house & 29 & 26 & 33 \\
\hline Parents' house & 60 & 62 & 56 \\
\hline Boarding house/hostel & 2 & 0 & 0 \\
\hline Other & $<1$ & 1 & 0 \\
\hline Highest school year for those 18 or over (\%) & $n=520$ & $n=161$ & $n=7$ \\
\hline Year 6-9 & 1 & 1 & 14 \\
\hline Year 10 & 3 & 4 & 86 \\
\hline Year 11 & 4 & 8 & 0 \\
\hline Year 12 or equivalent & 92 & 87 & 0 \\
\hline \multirow{2}{*}{$\begin{array}{l}\text { Trade or tertiary qualification for those } 18 \text { or over } \\
(\%)\end{array}$} & $n=521$ & $n=162$ & $n=8$ \\
\hline & 49 & 46 & 75 \\
\hline
\end{tabular}




\begin{tabular}{|c|c|c|c|}
\hline & $\begin{array}{l}\text { Expected drug dogs } \\
\text { and were intending } \\
\text { to take illicit drugs } \\
\qquad n=647\end{array}$ & $\begin{array}{c}\text { Saw drug dogs and } \\
\text { had illicit drugs on } \\
\text { their person } \\
n=190\end{array}$ & $\begin{array}{c}\text { Positively identified } \\
\text { by drug detection } \\
\text { dogs } \\
n=10\end{array}$ \\
\hline Employment $^{\mathrm{a}}$ & $n=608$ & $n=179$ & $n=9$ \\
\hline Part-time or casual work & 45 & 41 & 33 \\
\hline Full-time student & 39 & 32 & 11 \\
\hline Full-time work & 32 & 41 & 56 \\
\hline Unemployed (looking for work) & 4 & 3 & 0 \\
\hline Part-time student & 4 & 5 & 0 \\
\hline Self-employed & 3 & 3 & 0 \\
\hline Benefits & 1 & 0 & 0 \\
\hline Unemployed (not looking for work) & 1 & 1 & 0 \\
\hline Home duties (stay at home parent or carer) & 1 & 1 & 0 \\
\hline Main source of income $(\%)$ & $n=606$ & $n=179$ & $n=9$ \\
\hline Wage or salary & 82 & 88 & 89 \\
\hline Parental allowance & 8 & 3 & 0 \\
\hline Government & 5 & 4 & 0 \\
\hline Self-employment & 4 & 4 & 11 \\
\hline No income & 1 & 1 & 0 \\
\hline Criminal activity & $<1$ & 0 & 0 \\
\hline Other & 1 & 0 & 0 \\
\hline Total income per week (\%) & $n=567$ & $n=174$ & $n=8$ \\
\hline$\$ 1-249$ & 33 & 29 & 13 \\
\hline$\$ 250-599$ & 31 & 29 & 38 \\
\hline$\$ 600-999$ & 18 & 18 & 38 \\
\hline$\$ 1000-1599$ & 12 & 14 & 0 \\
\hline$\$ 1600-2800$ & 4 & 6 & 13 \\
\hline Greater than $\$ 2800$ & 1 & 2 & 0 \\
\hline Nil or negative & 1 & 1 & 0 \\
\hline
\end{tabular}

Note. Subsamples described in this table are not mutually exclusive. Percentages were rounded to the nearest whole number so totals may not equal $100 \%$.

${ }^{\mathrm{a}}$ Multiple responses were allowed so totals may exceed $100 \%$. 